\title{
PEMBAHASAN FIQIH WANITA DALAM PERSPEKTIF MAŻHAB SYAFI'IY DI PONDOK PESANTREN
}

\author{
Shofiyullahul Kahfi \\ IAINU Tuban \\ Email : shofiyullahulkahfi@stitmatuban.ac.id \\ Yudi Arianto \\ IAINU Tuban \\ Email : yudiarianto@stitmatuban.ac.id
}

\begin{abstract}
Abstrak
Ada begitu banyak alasan mengapa dibutuhkan kajian khusus tentang fiqih wanita. Salah satunya yaitu karena Allah SWT menciptakan wanita berbeda dengan laki-laki, baik secara fisik maupun psikis. Dan pada akhirnya syariat atau hukum-hukum yang Allah SWT turunkan kepada manusia juga banyak yang berbeda antara wanita dan laki-laki. Misalnya dalam permasalahan wanita saat menjadi saksi, dimana ketika seorang wanita menjadi saksi maka kesaksian tersebut dalam fiqih harus diperkuat dengan wanita lainnya. Sehingga jika wanita menjadi saksi dalam fiqih maka setidaknya dibutuhkan minimal dua wanita sebagai saksi, Itulah satu diantara sekian banyak alasan, begitu juga wanita secara psikis memang tidak bisa disamakan dengan psikis atau kejiwaan laki-laki. Hal tersebut menjadikan dalam Fiqih psikis wanita dan laki-laki mempunyai peran serta fungsi yang sangat berbeda dari keduanya. Dan dalam lingkup Mażhab Syāfíiy yang kita anut di Indonesia, ada beberapa rangkaian hukum yang khusus berlaku bagi wanita, yang perlu dibahas secara detail oleh para santri khususnya pembahasan di Pondok Pesantren.
\end{abstract}

Kata Kunci: Fiqih wanita, Fiqih Syāfi’iy, Mażhab Syāfi’iy , Pondok Pesantren

\section{PENDAHULUAN}

Dalam Kajian agama Islam kedudukan Wanita sangatlah Urgensi. Bahkan dalam Al Qur'an ada surat yang khusus dinamakan An-Nisā' (artinya wanita). Dalam Surat lain juga dibicarakan hal-hal yang berkaitan dengan wanita, di antaranya adalah peran wanita yang disamakan dengan laki-laki dalam berbagai ruang, seperti yang termaktub dalam QS Al-Ḥjurāat Ayat 13 :

يأيها الناس إنا خلقناكم من ذكر و أنثى و جعلناكم شعوبا و قبائل لتعارفوا إن أكرمكم عند الله أتقاكم إن الله عليم خبير

Artinya : Hai manusia, Sesungguhnya Kami menciptakan kamu dari seorang laki-laki dan seorang wanita dan menjadikan kamu berbangsa - bangsa dan bersuku-suku supaya kamu saling kenal-mengenal. Sesungguhnya orang yang paling mulia diantara kamu disisi Allah ialah orang yang paling taqwa diantara kamu. Sesungguhnya Allah Maha mengetahui lagi Maha Mengenal. 
- Hal ini menunjukkan bahwa Al Qur'an juga memperhatikan atau bisa dikatakan mengakui kedudukan wanita dalam kehidupan ini bahkan memperkuat jati dirinya dengan memberikan aturan aturan yang khas baginya sesuai dengan kodratnya.

Dalam Islam tidak mengenal diskriminasi atau penganakemasan terhadap satu golongan tertentu. Semua orang memiliki kedudukan yang sama di hadapan Allah, baik laki-laki maupun wanita. Adapun yang membedakan adalah tingkat keimannya. Bahkan Islam menegaskan posisi perempuan dalam masyarakat. Sampai saat ini sosialisasi ajaran Islam tetap menempatkan sosok perempuan dalam fiqh sebagai cerminan perempuan Islam yang ideal.(Siti Ruhaiani, 1996)

Sebenarnya al-Qur'an menempatkan wanita pada posisi sederajat dengan mitranya laki-laki dalam aktivitas kehidupan bermasyarakat. Namun, kenyataan sosial dewasa ini, memperlihatkan bahwa laki-laki diasumsikan sebagai sosok manusia yang lebih hebat, lebih pandai dari sisi intelektual dan profesi, tengah digugat dan dipertanyakan meskipun tangan tangan hegemonik lakilaki masih berusaha secara sadar atau tidak untuk tetap mempertahankannya.(Al-Qurțubiy, 1982:69)

Persepsi terhadap wanita di dalam agama Islam menarik untuk dicermati berkaitan dengan interpretasi yang telah terbiaskan oleh emosionalitas dan subjektivitas penafsir. Meskipun al-Qur'an adalah abadi dan berlaku universal, namun interpretasi terhadapnya tak luput dari sesuatu yang relatif dan subjektif. Dan Hal tersebut biasanya berkaitan dengan perkembangan historis berbagai Mażhab kalam, fiqih dan juga tasawuf.

Fiqih klasik mempertahankan dengan menekankan posisi instrumentalnya telah membawa stagnasi pemikiran terhadap permasalahan-permasalahan kaum wanita, yang dari masa ke masa selalu direduksi hanya untuk kepentingan di luar dirinya.

Prinsip keadilan dan kemaslahatan yang dicerminkan dan ditawarkan oleh fiqih tentang wanita atau fiqih yang konsen pembahasannya adalah seputar wanita, apalagi fiqih yang berafiliasi atau mengikuti pada Mażhab Imam Syāfi'iy RA, beliau adalah pencetus atau pendiri Mażhab Syāfi'iyah yaitu Mażhab yang berasal dari penggabungan mażhab Maliki dan fiqih mażhab Hanafi sebelumnya. Dari dua madzhab besar inilah kemudian beliau mendirikan sebuah madzhab fiqih yang kuat dengan penggabungan antara madrasah ahlul hadiśnya mażhab maliki dan madrasah ahlur ra’yiynya mażhab hanafi. (Muhammad Ajib, 2018:15).

Selanjutnya, tuntutan terhadap pemenuhan hak-hak wanita khususnya hak-hak semisal dalam memilih calon dalam perkawinan tidak bermaksud untuk menggeser posisi dan kedudukan laki-laki, akan tetapi lebih menekankan pada sebuah tatanan yang moderat, harmonis dan seimbang sehingga masing-masing dari mereka dapat saling menyadari posisinya dalam kedudukannya sebagai manusia yang mempunyai hak dan kewajiban. 
Dalam pesantren diajarkan juga beberapa ilmu terkait hukum hukum fiqih kepada seluruh santrinya baik laki-laki maupun wanita. Pesantren juga mengajarkan ilmu fiqih tanpa diskriminasi, terkhusus pada wanita diberikan pelajaran yang sesuai dengan kehidupannya sehari-hari seperti pembahasan seputar haidh dan lainnya. sehingga di pesantren ini kebanyakan santri wanita menguasai ilmu yang seharusnya dia semua wanita menguasainya. Sebab itulah, maka masyarakat semakin terbuka mengenai relasi sosial pada wanita di kehidupan masyarakatnya di kemudian hari. Hal ini pula yang memberi inisiatif mengubah corak pesantren (khusunya wanita) memberi ruang yang luas terhadap peran dan kiprahnya nanti mendidik masyarakat setelah pulang dari pesantren. (Karel A, 1994:36)

\section{ISI DAN PEMBAHASAN}

\section{Fiqih dalam Islam}

Kata fiqih yang diderivasikan dari faqiha-yafqahu wa fiqhan secara etimologi adalah: "Pengetahuan dan pemahaman tentang sesuatu". (Hafsah, 2013:3). Sedangkan secara terminologis (technical term) para Fuqahā' memberikan beberapa definisi:

Diantara nya yaitu fiqih merupakan ilmu tentang hukum-hukum syariat yang bersifat praktis dengan cara pencarian dalil. (Hafsah, 2013:4).

Ada empat unsur yang paling prinsip yang terkandung dalam tiga definisi tersebut, (Dede Rosyada. 1992:65) yaitu:

a. Ilmu ini berbicara tentang hukum-hukum syariat, sehingga selain cabangnya ini tidak dapat disebut dengan ilmu fiqih.

b. Hukum syariat tersebut berkaitan dengan perbuatan orang mukallaf yang bersifat praktis dan konkret, sehingga perbuatan manusia yang abstrak bukan termasuk wilayah atau kajian fiqih. Hal inilah yang dimaksud dengan wilayah otoritas ijtihad manusia, yaitu perbuatan manusia yang konkret, sedangkan perbuatan yang abstrak hal ini menjadi wilayah otoritas Tuhan, sebagaimana pernyataan Fuqahā':

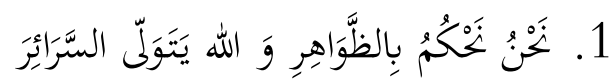

Artinya : "Kami hanya menetepkan hukum dengan tanda-tanda konkret (saja) dan Allah lah yang menghukumi dengan tanda-tanda abstrak".(Wahbah Az-Zuhailiy, 2012:661)

c. Pengetahuan itu diperoleh dengan cara ijtihad atau istidlāl, yaitu mencurahkan segala potensi dan kesempatan dalam rangka mencapai kesimpulan hukum yang diderivasikan dari sumber pokoknya. Dengan kata lain, bahwa ilmu ini hanya dapat diperoleh oleh orang-orang yang sudah mencapai kualifikasi mujtahid, bukan sembarangan orang bisa atau dengan cara hanya ingin main-main saja. 
d. Bahwa sumber-sumber hukum tersebut sudah terperinci menurut cabangnya masing-masing, baik yang bersifat pasti Qath`i maupun Zhanni.

\section{Fiqih dalam Pesantren}

Secara historis, eksistensi pesantren sebagai lembaga pendidikan Islam yang mengalami perkembangan pesat hingga kini di Indonesia tidak terlepas dari rangkaian sejarah yang sangat panjang. Proses pelembagaannya sudah dimulai ketika para pendakwah atau wali menyebarkan ajaran Islam pada masa awal sejarah Islam di Indonesia melalui masjid, surau, atau langgar (Zamakhsyari, 1982:49)

Dalam perkembanganya kemudian, pesantren menjadi tempat pendidikan dan pengajaran agama Islam untuk mencetak ulama, kiai atau ustadz yang menjadi pemimpin keagamaan di masyarakat. Pada masa modern, perkembangan pesantren ditunjukkan antara lain dengan memadukan sistem pendidikan sekolah, madrasah dan universitas. Pesantren pun akhirnya tidak menutup diri dari perkembangan gerakan dan wacana kontemporer seperti masalah-masalah demokrasi dan feminisme. Memperhatikan perkembagan itu, diakui oleh banyak kalangan bahwa kemampuan pesantren bertahan dan berkembang hingga sekarang menunjukkan kekuatannya untuk merespons perubahan masyarakat dari masa ke masa. Bersamaan dengan pergeseran kurikulum, pesantren juga mengalami perkembagan dan perubahan dalam bidang kemajemukan. Desakan modernisasi yang menimbulkan kesadaran di kalangan pesantren antara lain mengenai demokrasi, hak-hak asasi manusia dan emansipasi wanita atau feminisme. Pesantren dengan sendirinya didorong untuk merespons wacana wanita dan sekaligus mempertimbangkan kembali pandanganpandangan tradisionalnya yang cenderung berlawanan dengan gerakan wanita.

Kajian fiqih yang biasanya terkesan bias gender mengalami koreksi kritis dari dalam lingkugan pesantren sendiri.(Syafiq,1999:13) Meskipun melalui proses yang panjang dan bertahap, respons pesantren terhadap wacana wanita itu mempengaruhi aspek-aspek lain dalam sistem pesantren. Tuduhan sebagian kalangan bahwa dunia pesantren dianggap kurang mengapresiasi kiprah dan peran wanita dalam ranah publik tidak selamanya dibenarkan, karena ada sebagian kalangan ulama pesantren yang justru menempatkan wanita sama dengan laki-laki baik sebagai makhluk Tuhan maupun kiprahnya dalam ranah sosial-politik.

\section{Fiqih Syāfi'iy}

\section{Wanita dalam Pembahasan Aurat}


Aurat merupakan anggota tubuh pada perempuan dan laki-laki yang wajib ditutupi menurut agama dengan pakaian atau sejenisnya sesuai dengan batasan aurat masing-masing. Jika aurat itu dibuka dengan sengaja maka berdosalah pelakunya. Masing-masing dari perempuan dan laki-laki memiliki batasan aurat yang telah ditetapkan syariat Islam. Oleh karena itu, setiap muslim dan muslimah wajib untuk mengetahui batasannya dan kemudian mentaatinya dengan menjaga auratnya dalam kehidupan sehari-hari

Pengertian aurat menurut Syaikh Sa’ìd bin Muhammad Ba’alawi al-Haḍramiy dalam kitabnya Busyrā al-Karim adalah :

$$
\text { و (العورة) لغة: النقص، والشيء المستقبح، وسمي المقدار الآتي بها؛ لقبح ظهوره. وتطلق شرعاً: على ما يحرم نظره، }
$$

Artinya : "Secara etimologis, aurat berarti kurang, sesuatu yang menjijikan, dan terkadang sesuatu yang dianggap jijik akan dinamai dengan "aurat" karena dianggap jelek untuk diperlihatkan. Dalam terminologi syara', aurat berarti sesuatu yang haram untuk dilihat.” (Ba'alawi 2004:262)

Selanjutnya Imam Syāfí'iy dalam kitabnya Al-umm menyebutkan batasan aurat wanita dalam shalat yaitu :

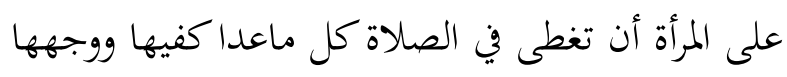

Artinya: Wajib atas wanita menutup selain dua telapak tangan dan wajahnya dalam shalat (Muhammad bin Idris, 1990:201)

Sedangkan aurat wanita di luar shalat dijelaskan oleh Imam Abū Ishāq Asy-Syairaziy dalam kitabnya Al-Muhażab :

$$
\begin{aligned}
& \text { أما الحرة فجميع بدها عورة إلا الوجه والكفين لقوله تعالى ولا يبدين زينتهن إلا ما ظهر منها قال ابن عباس: وجهها }
\end{aligned}
$$

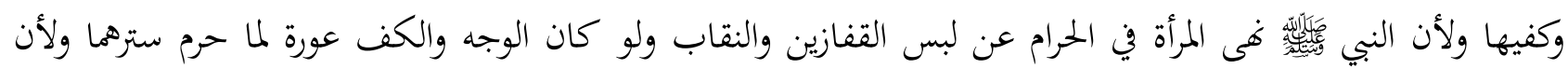

$$
\begin{aligned}
& \text { الحاجة تدعو إلى إبراز الوجه في البيع والشراء وإلى إبراز الكف للأخذ والإعطاء فلم يجعل ذلك عورة }
\end{aligned}
$$

Artinya: Adapun wanita merdeka, maka seluruh tubuhnya merupakan aurat, kecuali wajah dan dua telapak tangan. Hal ini berdasarkan firman Allah Ta'ala: "Dan janganlah mereka menampakkan perhiasan mereka, kecuali yang biasa nampak dari padanya". Ibnu 'Abbas berkata (mengomentari ayat ini), 'yang dimaksud adalah wajah dan dua telapak tangannya'. Dasar lainnya adalah karena Nabi SAW melarang wanita ketika ihram memakai sarung tangan dan cadar. Seandainya wajah dan telapak tangan merupakan aurat, Rasulullah tidak akan mengharamkan menutupnya. Alasan lainnya adalah karena adanya keperluan yang menuntut seorang wanita untuk menampakkan wajah dalam 
jual beli, dan menampakkan telapak tangan ketika memberi dan menerima sesuatu. Maka, tidak dijadikan wajah dan telapak tangan sebagai aurat.(Abū Ishāq, 1992:173)

Menurut Imam Ibnū Hajar dalam kitabnya disebutkan :

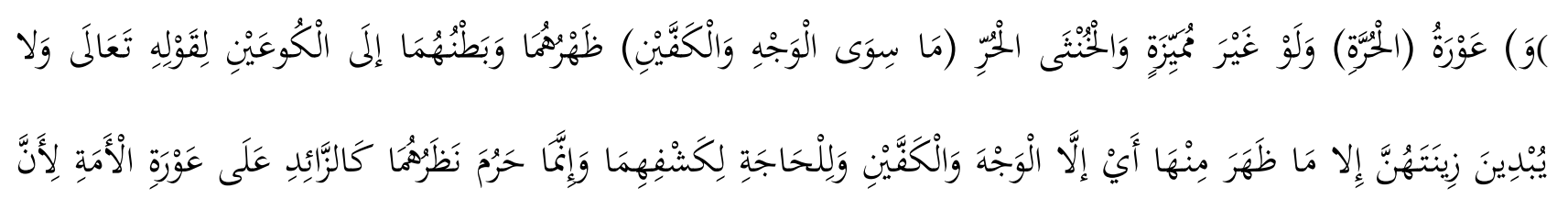

Artinya: Aurat wanita merdeka, meskipun dia itu belum mumayyiz dan aurat khuntsa merdeka adalah selain wajah dan dua telapak tangan, zhahirnya dan bathinnya sehingga dua persendiannya, berdasarkan firman Allah : "Dan janganlah mereka menampakkan perhiasan mereka, kecuali yang biasa nampak dari padanya", yaitu kecuali wajah dan dua telapak tangan. Alasan lain adalah karena ada keperluan membukanya. Hanya haram menilik wajah dan kedua telapak tangan seperti halnya yang lebih dari aurat hamba sahaya wanita, karena yang demikian itu berpotensi menimbulkan fitnah.(Ibnū Hajar, 1998:112)

Pada dasarnya, anggota tubuh perempuan yang boleh terbuka hanya wajah dan kedua telapak tangan, karena membuka wajah perempuan terkadang diperlukan seperti dalam jual beli. Demikian pula kedua telapak tangan dibutuhkan untuk mengambil dan memberikan sesuatu dalam berbagai kegiatan keseharian. (Abū Ishāq, 1992:219-220).

Disyaratkan juga tidak ada dugaan kuat ada pandangan syahwat dari laki-laki, maka tidak mengapa seorang perempuan membuka wajahnya diluar rumah dengan pemahaman seperti di atas, namun apabila terbuka wajah seseorang perempuan diduga kuat ada laki2 yang memandangnya (dengan sikap syahwat), maka itu menjadi haram membuka wajah baginya. (Syihāb Ad-Dīn, 1998:208)

\section{Wanita dalam Pembahasan Salat berjamaah}

Salat berjamaah lebih utama 27 derajat dari pada salat munfarid (sendirian). Begitulah yang disampaikan oleh Nabi Muhammad SAW. Begitu juga dalam kitab-kitab banyak sekali faḍilahfaḍilah atau keutamaan salat yang dilakukan secara berjamaah. Di antara keutamaannya adalah menjadi washilah terhindar dari api neraka sekaligus bisa menyelamatkan kita dari sifat munafik. Salat berjamaah juga mampu semakin meningkatkan peluang diterimanya salat dibanding dengan salat sendiri. Sampai-sampai ada ulama yang menyatakan bahwa tidak ada alasan Allah tidak menerima salatnya orang yang berjamaah. Padahal bisa diterimanya salat kita oleh Allah SWT membutuhkan berbagai macam persyaratan yang tidak ringan. Salat yang diterima oleh Allah 
dimulai dari dipenuhinya syarat sahnya salat dan rangkaian rukun yang harus dilakukan sesuai dengan kaidah yang sudah ditentukan oleh agama.

Menurut Imam Zakariyyā Al-Anșāriy (w. 926 H), salah satu ulama di kalangan Mażhab Syāfì'iyyah menuliskan dalam kitabnya Asnā al-Mațalib Syarh Raụ̣ Aț-Ṭālib sebagai berikut:

$$
\text { (و لا فرض فيها) اي الجماعة (على النساء بل تستحب) في حقهن }
$$

"Dan kaum wanita tidak wajib melakukan salat berjamaah akan tetapi disunnahkan". (Zakariyyā bin Muhammad al-Anșāriy, 2000:209)

Dan juga menurut Al-Māwardiy (w. 450 H), salah satu ulama di kalangan Mażhab syāfi’iyyah menuliskan dalam kitabnya Al-Hāwiy al-Kāir sebagai berikut:

$$
\text { من السنة لهن الصلاة في بيوتن دون المساجد }
$$

Artinya: "Disunnahkan bagi wanita alar di rumah-rumah mereka bukan di dalam masjid". (Abū Alhasan Al-Māwardi, 1426:163)

Dalam masalah keutamaan ini di dalam literatur fiqih diterangkan bahwa tidak ada perbedaan antara pahala yang didapatkan laki-laki dan wanita. Kemudian Apakah harus di masjid atau cukup di rumah dan bagaimana wanita yang berada di Pesantren? Dalam hal ini ulama menjelaskan lebih lanjut, bahwa, laki-laki lebih utama melaksanakan salat fardhu berjamaah di masjid dan wanita lebih utama melaksanakan salat fardhu berjamaah di rumah seperti yang disampaikan oleh Syaikh Abū Bakr bin Muhammad Ad-Dimyāti iyberikut :

$$
\begin{aligned}
& \text { والجماعة في مكتوبة لذكر بمسجد أفضل- وذلك لخبر: صلوا - أيها الناس - في بيوتكم، فإن أفضل الصلاة صلاة المرء } \\
& \text { في بيته إلا المكتوبة............... وخرج بالذكر المرأة، فإن الجماعة لها في البيت أفضل منها في المسجد }
\end{aligned}
$$

Artinya : Salat Fardhu berjamaah di masjid lebih utama bagi laki-laki hal tersebut berdasarkan hadits : salatlah kalian di rumah-rumah kalian karena salat yang paling utama adalah salatnya seseorang di rumahnya kecuali salat fardhu......dan di sini terdapat pengecualian bagi wanita. Untuk wanita salat berjamaah lebih utama dilaksanakan di rumahnya dari pada di masjid. (Abu Bakr, 2000:5)

Keterangan di atas terkait masalah lebih utama atau tidaknya, bukan masalah boleh atau tidaknya wanita melaksanakan salat berjamaah di masjid. Jadi, perbedaan pemahaman ini harus dijelaskan sehingga tidak disalahfahami oleh sebagian masyarakat ketika mengetahui sekilas pendapat di atas.

Begitu juga disampaikan Syaikh Muhammad Al-Khațīb al-Syirbīniy di dalam kitabnya Mughnī Al-Muḥtāj: 


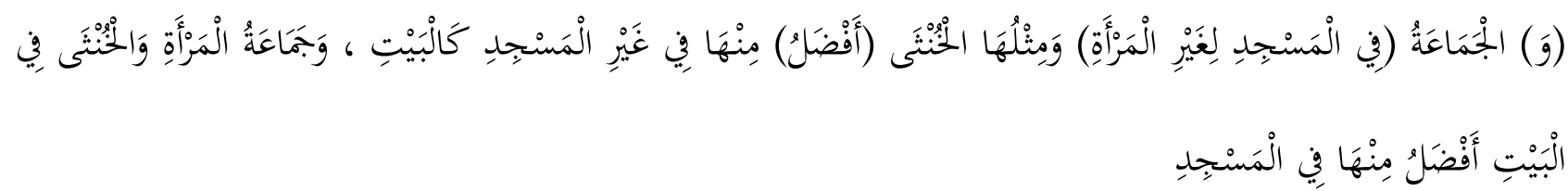

Artinya : Salat Jamaah di masjid bagi selain wanita - dan sesamanya wanita adalah khunșa - lebih utama dibandingkan dengan jamaah di selain masjid seperti di rumah dan jamaahnya perempuan dan Khunșa di rumah lebih utama dibandingkan jamaah di masjid (Muhammad Al-Khațib 1426:179).

Bahkan, diterangkan di dalam kitab yang sama tentang wanita yang memiliki keadaan menarik:

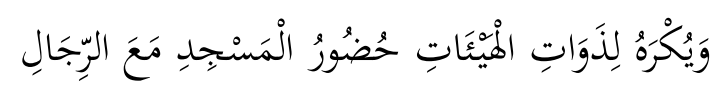

Artinya : Makruh bagi wanita yang "menarik" hadir di masjid bersama para lelaki. (Muhammad AlAl-Khațīb 1426:179)

Menurut Ar-Ramliy (w. 1004 H), merupakan salah satu ulama di kalangan Mażhab Syāfi'iyyah menuliskan dalam kitabnya Nihāyah al-Muhtāj sebagai berikut :

و يكره لما حضور جماعة المسجد إن كانت مشتهاة و لو في ثياب مهنة أو غير مشتهاة و بها شيء من الزينة أو الريح

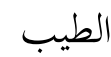

Artinya: "Dimakruhkan baginya (wanita) ikut Salat berjamaah di masjid jika dikhawatirkan menimbulkan syahwat (Muhammad bin Ahmad Syihābuddin Ar-Ramli, 1984: 140)

Dan menurut Imam Nawawiy dalam kitab Majmū'nya:

(فرع) قال اصحابنا لا تكون الجماعة في حق النساء فرض عين ولا فرض كفاية ولكنها مستحبة لهن ثم فيه وجهان

(أحدهما) يستحب لهن استحبابا كاستحباب الرجال (واصحهما) وبه قطع الشيخ أبو حامد وغيره لا تتأكد في حقهن

$$
\text { كتأكدها في حق الرجال فلا يكره لهن تركها وان كره للرجال. }
$$

Artinya : (Permasalahan cabang) Berkata Ashāb kita : Salat jamaah bagi perempuan tidak merupakan kewajiban yang 'ain dan bukan kewajiban Kifayah akan tetapi jamaah disunnahkan bagi mereka kemudian di dalam pendapat ini ada dua aspek : 1.Disunnahkan sekali bagi perempuan seperti disunnahkannya bagi lelaki 2. Pendapat yang lebih shahih dan pendapat ini diikuti oleh Imam Ghazali dan yang lainnya bahwa : terkait kesunnahan jamaah bagi wanita, tidak dikuatkan kesunnahan jamaah bagi wanita seperti dikuatkannya bagi lelaki, maka tidak makruh bagi wanita meninggalkan jamaah meskipun makruh meninggalkan bagi laki-laki.(Yahyā, 2009:188) 
Dengan pertimbangan di atas, maka dapat diambil kesimpulan terkait salatnya wanita di masjid atau di rumah, yaitu :

1. Salat wanita di rumah secara berjamaah lebih baik dari salat di masjid meski berjamaah, ini berlaku bagi setiap jenis wanita (tua/muda/menarik/dsb).

2. Salat wanita muda di rumah lebih utama dari di masjid meski di rumah sendirian dan di masjid jamaah, karena makruh hadirnya wanita muda di masjid sedang ia tidak makruh meninggalkan jamaah.

3. Salat wanita tua di masjid berjamaah lebih utama dari salat sendiri di rumah karena ia tidak makruh hadir di masjid dan sunnah jamaah.

Lantas bagaimana menyiasati salat wanita muda dalam hal ini santri wanita di lingkungan pesantren agar mendapatkan pahala jamaah, sementara santri laki-laki tetap mendapatkan keutamaan jamaah di masjid baik di lingkungan pesantren atau di lingkungan desa? Pilihan yang ditawarkan oleh pesantren adalah pihak pesantren putri telah membuat jamaah sendiri khusus bagi santri putri, tempatnya biasanya berada di aula pesantren putri atau di asrama masing-masing, jadi santri putri tidak ketinggalan akan pahala dari sholat berjamaah dengan santri-santri putera yang berada di masjid.

Sedangkan kalau cuma seorang semisal istri,yang sudah berada di rumah maka akan mudah mengontrolnya untuk salatnya menunggu suami pulang dari masjid dan i'ādah atau jamaah berdua dengan suami di rumah.

Berikut keterangan lebih lanjut, terkait salat berjamaah untuk suami dan istri, oleh Syaikh Ibrāhim Al-Baijūriy dalam kitabnya disebutkan :

$$
\text { وتحصل فضيلة الجماعة بصلاته بزوجته أو نحوها بل تحصيله الجماعة لأهل بيته أفضل. }
$$

Artinya: Seorang laki-laki juga mendapatkan keutamaan salat berjamaah dengan melaksanakannya bersama istri atau keluarga yang lain, bahkan pelaksanaan salat berjamaah bersama keluarga di rumahnya lebih utama. (Syaikh Ibrāhim Al-Baijūriy, 2009:250)

Pendapat-pendapat tampaknya condong untuk bahkan membiarkan istri salat sendiri daripada suami tidak ke masjid. Dan secara logika, kalau semua suami mengambil kebijakan salat dengan istri di rumah karena kalau istri ke masjid makruh misalnya, maka masjid akan cenderung kosong. Namun kalau ahli rumahnya banyak seperti diungkap dalam ibarot Mughni Al-Muhtāj di atas, maka akan sulit mengontrol untuk menunggu suami pulang karenanya langsung dikatakan lebih afdhol jamaah di rumah. Wallāhu a'lamu bișṣowāb.

\section{Wanita dalam Pembahasan Memilih Calon}


Didalam Kompilasi Hukum Islam (KHI) bagian ketiga Pasal 19 disebutkan sebagai berikut: Wali nikah dalam perkawinan merupakan rukun yang harus dipenuhi bagi calon mempelai wanita yang bertindak untuk menikahkannya.

Imam Syāfi'iy dan kebanyakan para ulama berpendapat bahwa nikah tidaklah sah dengan cara dilaksanakan sendiri oleh wanita atau walinya. Wali adalah orang yang berwenang untuk melangsungkan akad pernikahan atas diri seorang wanita, dan ia tidak boleh membiarkan wanita itu melangsungkan akad tanpa dirinya karena wali adalah syarat sahnya pernikahan, jika seorang wanita menikahkan dirinya sendiri, maka nikahnya batil.(Ibnu Mas’ud, 2007:270).

Adapun dalil 'aqliy (logika) ialah bahwa nikah itu mempunyai berbagai tujuan. Pernikahan adalah ikatan antara keluarga. Wanita dengan kekurangannya dalam memilih, tentulah tidak dapat menjatuhkan pilihan dengan cara yang baik, terutama lagi karena wanita itu memiliki perasaan lemah lembut, yang kadang-kadang menutupi segi kemaslahatan. Untuk menghasilkan tujuan-tujuan ini yang lebih sempurna, dilaranglah wanita mencampuri secara langsung akad nikah.

Al-Khatīb Asy-Syirbīniy (w. 977 H), salah satu ulama di kalangan Mażhab Syāfi'iyyah menuliskan dalam kitabnya Mughnī Al-Muhtāj sebagai berikut :

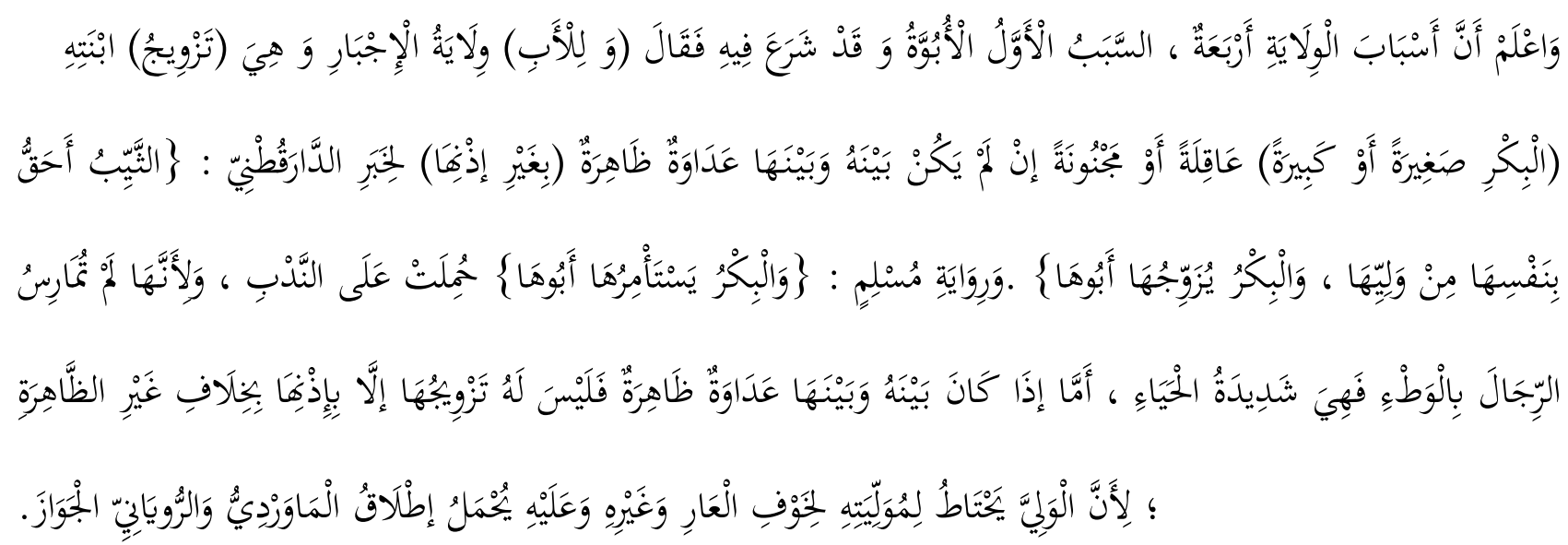

Artinya: Sesungguhnya sebab menjadi wali itu ada empat, salah satunya karena ia adalah ayahnya, dan telah disyari'atkan bahwa bagi seorang ayah untuk memaksa anaknya untuk menikah baik ia perawan yang masih kecil ataupun sudah besar, berakal atau gila, tanpa izin anaknya selama belum ada permusuhan yang nampak antara seorang anak dan ayahnya, seperti khabarnya Dār AlQuțni: śayyib (janda) dia lebih berhak atas dirinya daripada walinya, dan perawan dinikahkan oleh walinya. Dan dari riwayat muslim: "dan bagi seorang perawan sang ayah harus meminta izin kepadanya" perintah dalam riwayat ini hukumnya Sunnah, karena anaknya belum berpengalaman dalam masalah pernikahan dan ia sangat pemalu. Akan tetapi, apabila ada permusuhan yang nampak antara mereka, maka sang ayah tidak boleh menikahkannya kecuali meminta izinnya tapi kalau tidak nampak tidak apa-apa, karena ayahnya sangat menjaga anaknya dari aib dan lainnya, Māwardi 
mengambil pendapat ini secara mutlak dan bagi Rauyānī jaiz.. (Muhammad Al-Khațịb AsySyirbiniy. 1426:246)

Secara umum penyebab adanya perwalian di dalam perkawinan adalah sebagai berikut: a. Wali Ubuwwah (hubungan bapak), yang termasuk di dalamnya adalah bapak dan kakek dan nasab ke atas. b. Wali 'Așabah, yang termasuk diantaranya adalah saudara kandung, saudara sebapak, anak dari saudara kandung, anak dari saudara sebapak, paman sekandung, paman sebapak, anak dari paman sekandung, anak dari paman sebapak, pamannya bapak, anaknya pamannya bapak. c. Wali sebab memerdekaan, wali ini dimiliki oleh Sayyid (tuan) yang pernah memerdekakan budaknya. d. Wali Imam, yakni perwalian oleh seseorang pemimpin yang dimaksudkan adalah qaḍi (hakim).

Al-Māwardi (w. 450 H), salah satu ulama di kalangan Mażhab Syāfi'iyyah menuliskan dalam kitabnya Al-Hāwi Al-Kabirir sebagai berikut :

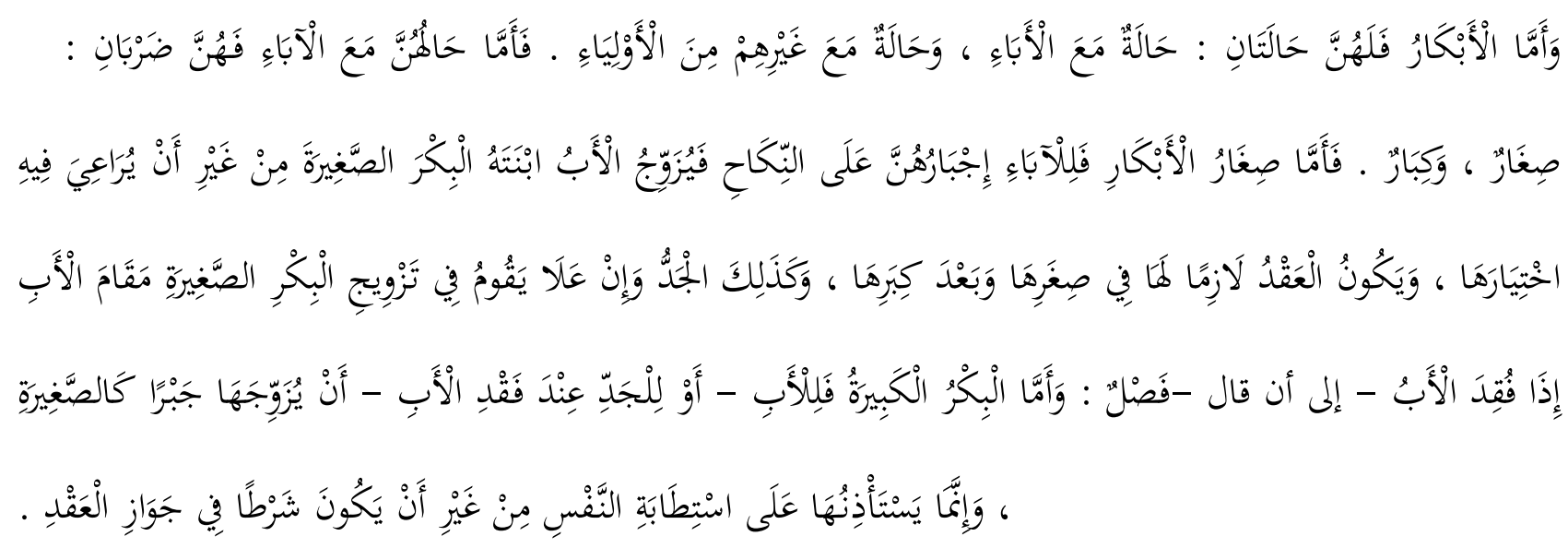

Artinya :Bagi wanita-wanita perawan dibagi menjadi dua keadaan yaitu ketika mereka masih bersama dengan ayah mereka dan ketika bersama dengan wali-wali selain ayah mereka. maka ketika mereka bersama dengan ayah mereka ini juga dibagi kembali menjadi dua: perawan șighar (yang belum bāligh) dan perawan kibār (yang sudah bāligh) perawan yang masih kecil atau belum baligh itu boleh dipaksa oleh ayahnya untuk menikah, maka sang ayah boleh menikahkan anak wanitanya yang masih perawan yang masih kecil tanpa harus memperhatikan keputusannya atau pilihannya, dan akadnya menjadi lazim baginya selama masa kecilnya sampai ia dewasa, begitupula bagi sang kakek dan seterusnya, atau seseorang yang dapat menikahkannya ketika ayahnya sudah tiada. Sampai perkataan -Pembahasan perawan yang sudah besar atau dewasa maka boleh bagi ayahnya atau kakeknya ketika tidak ada ayah untuk menikahkannya secara paksa seperti perawan yang masih kecil, untuk masalah izin kepadanya hanya sekedar perlakuan baik dan bukan syarat sahnya akad . (Abū Al-Hasan al-Māwardiy, 1426:52)

Wali dalam pernikahan menurut Imam Syāfí'iy dibagi menjadi dua bagian, yaitu wali Nasab dan wali hakim, penjelasannya adalah sebagai berikut: a. Wali Nasab yaitu seseorang yang berhak 
melakukan akad pernikahan dari calon pengantin wanita berdasarkan hubungan darah (keturunan) antara dia dengan calon pengantin wanita tersebut. Wali nasab bila dilihat dari dekat dan jauhnya hubungan darah (keturunan) dengan calon pengantin wanita b. Wali Imam, yakni perwalian oleh seseorang pemimpin yang dimaksudkan adalah qadi (hakim).

\section{Hak Ijbar}

Hak ijbār merupakan suatu kekuasaan yang diberikan kepada seseorang (wali mujbir) untuk menikahkan anak wanita yang berada dalam perwaliannya walaupun tanpa dimintai persetujuannya. Menurut Imam An-Nawawī (w. 676 H), salah satu ulama di kalangan Mażhab Syāfi’iyyah menuliskan dalam kitabnya Raudhah Aț-Ṭalibin terkait nikahnya perawan dan yang lainnya, sebagai berikut :

$$
\text { فلأب تزويج البكر الصغيرة والكبيرة بغير إذها ويستحب استئذان البالغة ولو أجبرها صح النكاح فلو كان بين الأب }
$$

Artinya : Seorang ayah boleh menikahkan "perawan” yang masih anak-anak (belum bāligh) dan dewasa (sudah bāligh) tanpa meminta izin, dan sunnah meminta izin kepada "perawan"e yang sudah bāligh. Dan jika sang ayah menikahkannya dengan paksa maka nikahnya sah, meskipun antara wanita dan ayahnya tampak permusuhan yang jelas. Sedangkan "śayyib", maka sang ayah tidak boleh menikahkannya tanpa izin ketika dia sudah bāligh, dan kedudukan kakek sama seperti ayah dalam hal ini. (An-Nawawī, 1991:53)

Dan juga menurut beliau dalam kitabnya yang lain yaitu Al-Majmu>' Syarh Al-Muhażab menjelaskan lebih lanjut sebagai berikut :

$$
\begin{aligned}
& \text { أحق بالبكر وإن فدل على أن الولى......ويجوز للاب والجد تزويج البكر من غير رضاها صغيرة كانت أو كبيرة } \\
& \text { كانت بالغة فالمستحب أن يستأذها للخبر وإذها صماتا...... ولاها تستحى أن تأذن لابيها بالنطق فجعل صماتا إذنا، } \\
& \text { ولا يجيوز لغير الاب والجد تزويجها إلا أن تبلغ و تأذن...... وأما الثيب فإنها ان ذهبت بكارةا بالوطئ فان كانت بالغة } \\
& \text { عاقلة لم يجز لاحد تزويجها إلا بإذها. }
\end{aligned}
$$

Artinya: Ayah dan kakek boleh menikahkan perawan tanpa izinnya baik dia anak-anak (belum bāligh) atau sudah dewasa (sudah bāligh)...dan ini menunjukkan bahwa wali lebih berhak atas perawan. Dan jika dia sudah bāligh maka disunnahkan meminta izinnya, dan izinnya adalah diam, karena dia malu untuk mengungkapkan secara lisan kepada sang ayah bahwa dia mengizinkan maka diamnya adalah izin, dan selain ayah dan kakek tidak boleh menikahkannya tanpa izin. Sedangkan 
"śayyib" yang telah hilang kegadisannya karena jimā', jika sudah bāligh dan berakal maka siapapun tidak boleh menikahkannya tanpa izinnya. (Yahyā bin Syaraf. 2009:165)

Wali Mujbir adalah wali yang berhak menikahkan orang yang berada di dalam perwaliannya, sifatnya adalah memaksa dan berfsifat wajib untuk di lakukan walaupun tanpa seizin darinya.34 2) sedangkan, Wali Ghoīu Mujbir adalah kebalikan dari wali mujbir, yaitu wali yang berhak menikahkan seseorang yang berada di dalam perwaliannya tetapi sifatnya tidak memaksa dan tidak wajib untuk dilakukan. Melainkan hanya sekedar berhak untuk menikahkan saja. (Ali Ibn 'Umar AlDaruqutni, 2004:322-3223).

Dari keterangan di atas diambil kesimpulan bahwa: Hak ijbār harus dimaknai sebagai bentuk perlindungan atau tanggung jawab seorang ayah terhadap anaknya karena adanya anggapan bahwa anak wanitanya belum atau tidak memiliki kemampuan untuk bertindak sendiri dalam pernikahan. Adanya anggapan itu mengindikasikan adanya bias gender dalam keluarga yang menganggap wanita lemah akal. Wallāhu a'lamu bișșowāb.

\section{Wanita dalam Pembahasan Nafkah}

Memenuhi kebutuhan istri merupakan kewajiban utama seorang suami. Kebutuhan yang dimaksud tidak hanya kebutuhan materi, tapi juga kebutuhan non-materi. Selain mencukupi kebutuhan istri, seorang suami juga mesti menafkahi anak-anaknya sampai mereka dewasa dan mandiri. Kedua hal ini sudah menjadi tanggung jawab suami dan konsekuensi berumah tangga.

Sebetulnya ada tujuh perkara yang menjadi hak seorang istri atas suaminya, yang dikumpulkan oleh ulama dalam syair berikut :

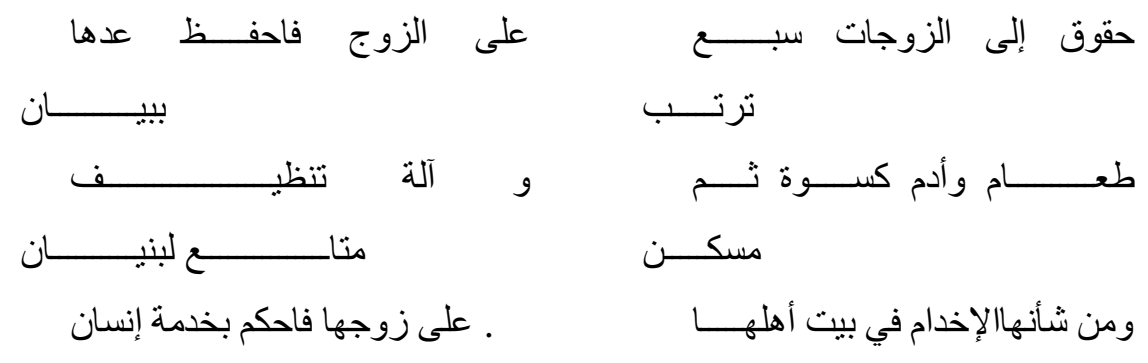

Artinya : Hak-hak seorang istri atas suaminya ada 7 : Memberikan makanan pokok, Memberikan lauk pauk, Memberikan pakaian, Memberikan tempat tinggal, Memberikan alat bebersih, Memberikan perabot rumah tangga, Memberikan pembantu (apabila memang di rumahnya dahulu ada pembantu). (Muhammad Nawawi, 2015:378)

Menurut Imam Asy-Syāfi'iy (w. 204 H), ulama pendiri mazhab Syāfi'iy menuliskan dalam kitabnya Al-Umm sebagai berikut :

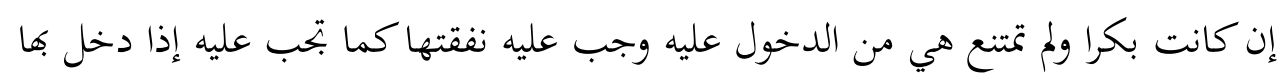


Artinya : Wanita perawan berhak mendapatkan nafkah dari suaminya jika tidak ada penghalang terjadinya Jimā', sebagaimana ia berhak mendapatkan nafkah setelah dijimā'. (Muhammad bin Idris Asy-syāfi'iy, 1990:96)

Hal serupa juga disampaikan oleh Syaikh Zainudin Al Malibariy (w. 987 H), salah satu orang yang alim dari mazhab Syāfi'iy menuliskan dalam kitabnya Fath Al-Mu'in sebagai berikut :

يجب المد الآتي و ما عطف عليه (لزوجة) أو أمة و مريضة (مكنت) من الإستمتاع بها و من نقلها إلى حيث شاء عند

أمن الطريق و المقصد و لو بركوب بحر غلبت فيه السلامة فلا بجب بالعقد خلافا للقديم

Artinya : "Wajib menafkahi satu mud yang akan diterangkan dan yang diaṭafkan (bagi istri) atau budak wanita dan istri yang sedang sakit (yang mungkin jimā') bersenng-senang dengan istri dan seseorang yang memindahkannya pada tempat yang dikehendaki ketika dirasa aman dalam perjalanan dan tujuan walaupun dengan melewati laut yang kemungkinan besar keselamatannya maka tidak wajib memberikan Nafaqah sebab "Aqad berbeda halnya pendapat qaul qadim." (Zainuddin Al-MaTibariy, 2000: 60)

Dalam keputusan Bahśul Masa`il di pesantren diterangkan bahwa kewajiban suami dalam menafkahi istri nya tergantung kemampuannya. Maka untuk kewajiban memberikan nafkah ini pun berbedabeda, bagi seorang suami yg tidak mampu (seorang yang tidak memiliki harta untuk keluar dari kemiskinannya) setiap hari adalah 1 mud makanan pokok (sang istri), dan bagi suami yang mampu (kaya) adalah 2 mud, sedangkan bagi suami yang biasa-biasa saja (tidak masuk kategori kaya dan tidak pula miskin ) adalah 1,5 mud. Dan diberikan setiap hari di waktu pagi, ini semua apabila istri makan sendiri tanpa suami, apabila bersamaan makannya maka suami tetap berkewajiban mencukupi keperluan tersebut. Serta mencukupi keperluan yang telah disebutkan diatas semisal lauk pauk, pakaian, dll. (Zainuddin, 2000:119)

Dan sebaiknya suami istri bermusyawarah dalam masalah ini sehingga tidak ada hak-hak ataupun kewajiban yang terabaikan sehingga nantinya timbul kerelaan dari pihak istri ataupun suami.

Konteks zaman pada pembuatan konsep kadar nafkah istri adalah masa dimana Imam Syāfi'iy masih hidup sehingga segala sesuatu yang berkaitan dengan penerapan kadar nafkah istri tersebut disesuaikan dengan kebutuhan para istri pada masa itu. Sebagaimana pada jumlah kadar minimal nafkah istri oleh suami yang disebutkan dalam satuan mud. Asal pemilihan satuan mud adalah karena pada saat penetapan konsep kadar nafkah istri, Imam Syāfi'iy menganalogikan nafkah istri dengan jumlah kafarat yang satuan bayarnya menggunakan mud serta karena di antara keduanya memiliki kesamaan sifat yaitu merupakan harta yang dapat dihitung. Selain itu, penggunaan satuan 
mud merupakan bentuk ukuran untuk menghindari perbedaan yang timbul jika menggunakan ukuran mata uang yang berlaku pada saat itu. (Syamsuddin Ar Ramliy, 2009:295).

Namun Jika dibandingkan dengan saat ini, jumlah mud di atas telah dikonversikan dalam satuan kilogram yang berlaku di negara Indonesia. Maka jumlahnya sekitar dengan 0,6 ons. Atau dibulatkan sampai 7 Ons. Pada jumlah tersebut, jika dijadikan sebagai patokan minimal nafkah suami kepada sang istri maka tidak akan mampu memenuhi seluruh kebutuhan rumah tangga dalam kesehariannya. Dan benar jika diterapkan pada masa Imam Syāfi'iy jumlah tersebut mampu memenuhi seluruh kebutuhan rumah tangga. Namun jika diterapkan pada saat ini dengan kondisi harga bahan makanan pokok yang tidak stabil, maka ketentuan kadar tersebut tidak akan mampu mengakomodir kebutuhan dalam rumah tangga. Wallāhu a'lamu bișṣowāb.

\section{Wanita dalam Pembahasan Warisan}

Hukum Islam mengatur jika wanita juga berhak mendapatkan harta warisan. seperti halnya laki-laki. Menurut Imam Taqiyuddin Al-Hișniy salah satu ulama Mażhab Syāfi’iy di dalam kitabnya Kifāyat Al Akhyār beliau menerangkan :

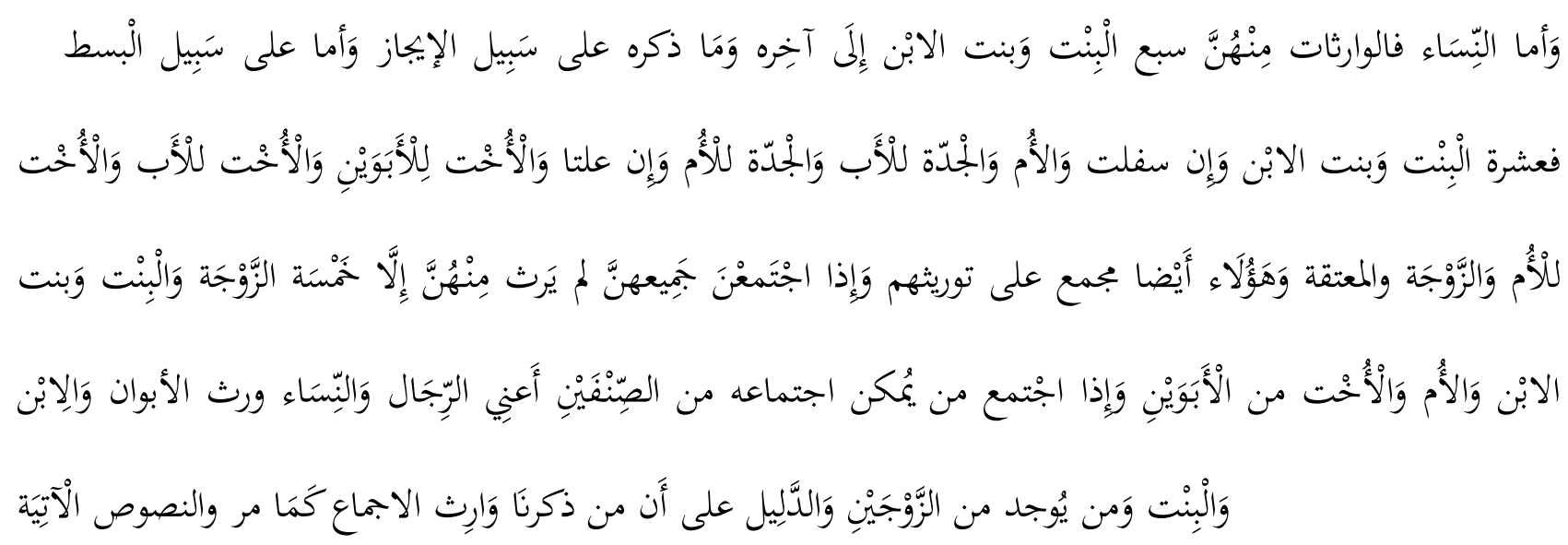

Artinya : "Adapun ahli waris dari kalangan wanita ada 7 orang, yaitu: anak, cucu wanita dari anak laki-laki sampai berjumlah 7 orang yang disebut secara ringkas. Sebenarnya jika dirinci, ahli waris wanita itu berjumlah 10 orang: anak wanita, cucu wanita dari anak laki-laki sampai ke bawah, ibu, nenek dari bapak dan nenek dari ibu terus ke atas, saudari kandung, saudari sebapak, saudari seibu, istri dan .. Semua orang ini adalah ahli waris menurut Ijmā' ulama. Jika mereka semua ada sebagai ahli waris, maka hanya ada 5 orang yang saat itu berhak mendapatkannya, yaitu: istri, anak wanita, cucu wanita dari anak laki-laki, ibu dan saudari kandung. Jika mungkin semua laki-laki dan wanita ini ada sebagai ahli waris, maka hanya kedua orang tua, anak laki-laki dan anak wanita dan suami atau istri. Dalil apa yang kami sudah sebutkan ini adalah Ijmā’ulama dan naṣ-naṣ yang akan datang." (Abū Bakr bin Muhammad Al-Hișniy, 2000:26) 
Di dalam islam, warisan yang diberikan orang tua untuk seorang wanita berjumlah separuh dari seorang laki-laki.

Terkait hukum dalam waris ini, Allah swt telah banyak membicarakannya di dalam Al Qur'an, di antaranya dalam Alquran surat An-Nisā' :

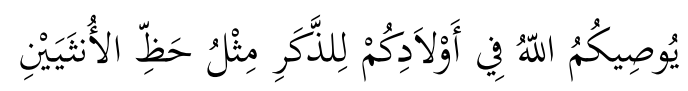

Artinya : "Allah mensyari'atkan bagimu tentang (pembagian pusaka untuk) anak-anakmu. Yaitu : bahagian seorang anak lelaki sama dengan bagian dua orang anak wanita.” (QS. An Nisā’: 11)

Hikmah dari bagian ahli waris laki-laki lebih banyak dari wanita di antaranya adalah karena laki-laki punya beban atau tanggung-jawab menafkahi keluarga yang lebih, sedangkan wanita tidak diwajibkan atas beban tersebut. Laki-laki punya beban kerja yang tidak mampu dilakukan wanita seperti memberi biaya makan, minum, pakaian, obat-obatan, pendidikan, tempat tinggal, hingga menggaji asisten rumah tangga.

Karena itu, suami harus bekerja keras untuk menghidupi keluarganya. Istri pun tidak memiliki kewajiban untuk menafkahi keluarganya sepeser pun. Kewajiban istri sebatas pada meng awasi ketertiban dan kenyamanan rumah tangga. Jika istri masih memiliki waktu luang untuk pekerjaan kemasyarakatan yang disesuaikan bakat dan pendidikan, dia tetap tidak dibebani tanggung jawab atas nafkah rumah tangga. Seandainya dia mendapat penghasilan dari pekerjaannya, maka, dia berhak menguasai sepenuhnya atas harta tersebut. Dia bahkan bisa memberikan zakat kepada suaminya jika suaminya tergolong orang yang miskin. Sebaliknya, suaminya tidak bisa memberi zakat kepada istrinya karena istri merupakan orang yang wajib dinafkahi oleh suami. (ATi Ahmad Al-Jurjāwi. 2012:262)

Begitu juga, jika seorang wanita menikah, maka semua keperluan hidupnya menjadi tanggungan suaminya. Sementara, bagian yang dia peroleh dari harta warisan bisa diinvestasikan atau dibelanjakan untuk kepentingan dia sendiri. Dari sini, dapat dipastikan jika bagian wanita yang separuh dari lelaki itu jauh lebih menguntungkan ketimbang bagian laki-laki. Belum lagi hak-hak istimewa wanita yang diatur dalam Islam di luar hukum waris. Wanita punya hak untuk memiliki harta sendiri tanpa sedikit pun hak bagi orang lain, baik orang tua maupun suaminya dan siapa pun juga untuk ikut campur di dalamnya. Mereka tak berhak melakukan perdagangan atau transaksi lainnya tanpa kerelaan penuh dari wanita. (Ali Ahmad Al-Jurjāwi. 2012:264)

Akan tetapi, pola di masyarakat di Indonesia berbeda sekali dengan yang berarada di arab memang seorang laki-laki dituntut penuh menopang kebutuhan keluarga, sedangkan di sini, kadang seorang suami ikut istri, kadang istri ikut suami, dan yang terjadi kebanyakan hukum bagi rata untuk harta 
milik orang tua, jadi tidak tepat disebut warisan, tapi hibah, karena kebanyakan sudah dibagi-bagi sebelum orang tua meninggal.

Terkait dengan hibah ini pula, maka, sebaiknya dibagi secara merata kepada seluruh anak-anaknya, sebagaimana pendapat jumhur ulama. Namun dibolehkan melebihkan bagian seorang anak tertentu dari anak-anak yang lainnya manakala memang hal itu diperlukan, seperti : untuk biaya pengobatannya, melunasi utang-utangnya, karena anaknya banyak, bekal pendidikannya atau yang lainnya, sebagaimana riwayat dari Ahmad (Wahbah Al-Zuhailiy. 2012:414). Namun jika pembagian hibah kepada anak-anak tertentu tidak memiliki alasan yang dibenarkan maka harta hibah itu perlu kembali diperhitungkan. Wallāhu a'lamu bișșowāb.

\section{PENUTUP}

Fiqih Mażhab Syāfi'iy cukup berkembang luas di kawasan Asia Tenggara, begitu juga Mażhab Syāfi'iy yang mewarnai pendidikan pesantren diseluruh Indonesia. Mayoritas masyarakat Islam di Indonesia memegang teguh Mażhab Syāfi'iy dalam menjalankan dan melaksanakan ritual agamanya dalam kehidupan sehari-hari.

Dan ilmu fiqih Mażhab Syāfi'iylah yang telah memberikan gambaran terperinci tentang pembahasan wanita diseluruh sisi kehidupannya, baik ranah umum maupun ranah khusus. Yang sering banyak dibahas dalam fiqih adalah pembahasan yang terkait dengan hukum, karena memang di sinilah ranah fiqih Islam. Pembahasan wanita terutama yang banyak dibahas dalam Fiqih Mażhab Syāfi'iy antara lain: Pembahasan Aurat, Pembahasan Sholat berjamaah, Pembahasan Dalam Menentukan calon, Pembahasan Nafkah, Pembahasan Warisan.

\section{DAFTAR RUJUKAN}

Abū Al-Hasan al-Māwardiy. 1426 H. Al-Hawì Al-Kabïr. Beirut: Dar al-Fikr.

Abū Bakr bin Muhammad al-Hiṣniy. 2000. Kifāyat al-Akhyār Fï Halli Ghāyat al-Ikhtị̣ār, Beirut: Muassasah al-Risalah.

Abū Bakr bin Muhammad Ad-Dimyātị. 2000. I'ānat Al- Ṭālibỉn. Semarang:Ṭoha Putra

Abū Ishāq Ibrāhīm As-Syīraziy. 1992. Al-Muhaddzab fi Fiqhil Imāmis Syāfíiy. Beirut : Darul Qalam.

Ali Ahmad al-Jurjāwiy. 2012. Hikmatuttasyrī' Wa Falsafatuhu. Beirut :Darul Fikr.

Ali Ibn 'Umar Al-Daruqutni. 2004. Sunan Al-Dāru Quṭnī. Beirut Lebanon: Aresalah Pubisher. Al-Qurthubi. 1982 Al-Jāmi' li Ahkām al-Qur 'an. Cairo:Dar al-Kātib. 
An-Nawawiy. 1991. Rauḍatu Ath-Ṭālibỉn, Beirut: Al-Maktab al-Islami.

Ba'alawiy Muhammad. 2004. Busyro Al Karim. Jeddah:Dar Al Minhaj.

Dede Rosyada. 1992. Hukum islam dan Pranata sosial. Jakarta : Raja Grafindo

Hafsah. 2013. Pembelajaran fiqih. Bandung:Cita pustaka Media Perintis.

Ibnu Hajar al-Haitamy. 1998. Tuhfah al-Muhtāj. Mesir, Mathba'ah Mushthafa Muhammad.

Ibnu Mas’ud. Zainal Abidin. 2007.Fiqih Mażhab Syafi’i 2. Bandung: Pustaka Setia.

Ibrāhim Al-Baijūriy . 2009. Hasyiyah Al-Bajuri Ala Syarhi ibn Qosim Beirut : Darul Qalam.

Karel A. Steenbrink. 1994. Pesantren Madrasah Sekolah: Pendidikan Islam dalam Kurun Modern. Jakarta: LP3ES.

Muhammad Al-Khațịb al-Syirbīniy. 1426 H. Mughnī al-Muhtājj. Beirut: Dar al-Fikr.

Muhammad bin Idris Asy-Syāfi’iy. 1990. Al-Umm. Beirut: Dar al-Marifah.

Muhammad Idris Ramulyo. 1974 Hukum Perkawinan Islam. Jakarta: Bumi Aksara.

Muhammad Nawawi bin Umar Al-Jawi. 2015 Nihāyat Az-zain. Jakarta:Darul Kutub Islamiyah

Syamsuddin Al-Ramliy. 2009. Nihāyat al-Muhtạj Ilā Al-Syarh al-Minhāj. Lebanon: Dar al-Kutub al-Ilmiyah,.

Syafiq Hashim. 1999. Menakar Harga Wanita Bandug: MIZAN.

Syihabuddin Abu al-‘Abbas al-Qalyubi. 1998. Hāsyiyah Qalyūbi ‘ala Syarh al-Mahalliy 'ala Minhāj al-Thalibin . Beirut : Darul Qalam.

Wahbah Al-Zuhailiy. 2012. Al Fiqhul Islamiy Wa Adillatuhū. Beirut:Darul Fikr

Yahyā bin Syaraf An-Nawawiy. 2009. Al-Majmū' Syarah Al-Muhażab. Beirut: Dar al-Fikr.

Zakariyyā bin Muhammad al-Anșāriy. 2000. Asnal Maṭālib Syarh Raudhu Ath-Ṭālib. Beirut: Dar al-Kutub al-Ilmiyyah.

Zainuddin Al-MaTibari, 2000 Fathul Mu'īn bisyarhi qurrotul 'ain. Semarang:Thoha Putera.

Zamakhsyari Dhofier, 1982. Tradisi Pesantren : Studi Tentang Pandangan Hidup Kyai. Jakarta:LP3ES. 